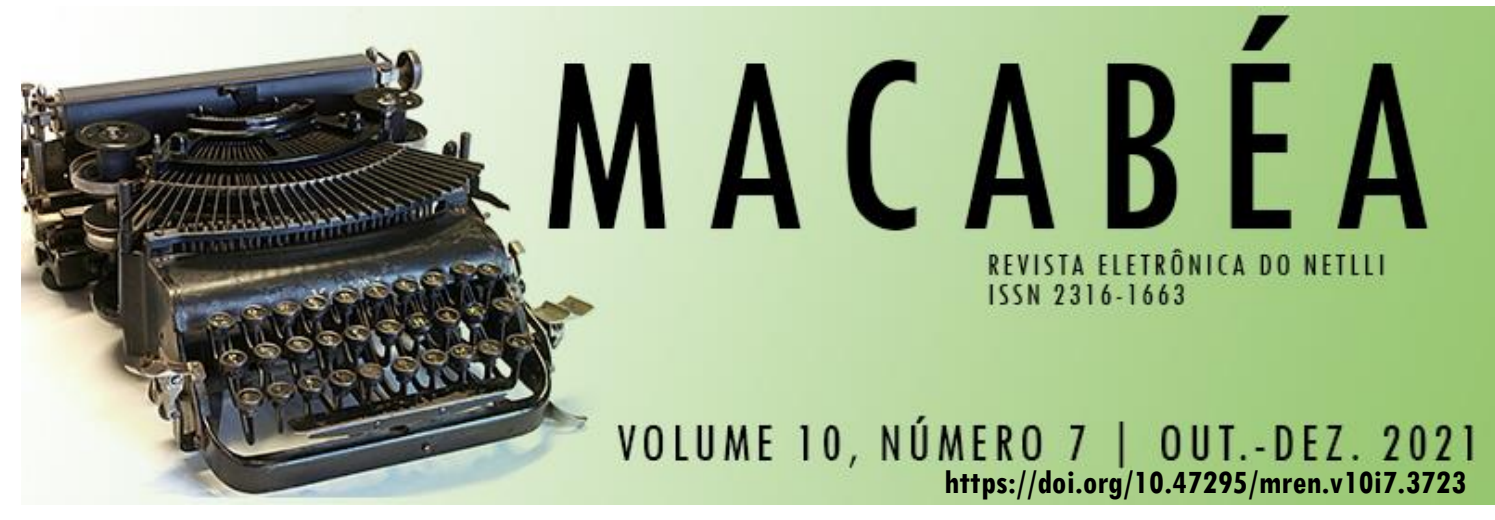

\title{
O PERDÃO, DE ANDRADINA DE OLIVEIRA: UMA DENÚNCIA DO DISCURSO PATRIARCAL
}

\section{O PERDÃO(THE FORGIVENESS), BY ANDRADINA DE OLIVEIRA: DENUNCIATION OF PATRIARCHAL DISCOURSE}

ALEXANDRA SANTOS PINHEIRO

SELMA ALVES SOUZA

\section{RESUMO | INDEXAÇÃO | TEXTO | REFERÊNCIAS | CITAR ESTE ARTIGO | AS AUTORAS RECEBIDO EM 30/07/2021 • APROVADO EM 11/09/2021}

\begin{abstract}
In this text, we discuss the representation of the repressive patriarchal society of the early twentieth century from the perspective of the writing of Andradina de Oliveira. The books 0 perdão (1910) is revealing of the dominant discourse in this period and presents female characters moved by the feeling of transgression when assuming their sexual desire. From the perspective of gender studies, we seek to highlight the questions and ruptures of the domination practices presented by the writer Andradina de Oliveira in an urban novel set in the Belle Époque rio-grandense.
\end{abstract}

\section{Resumo}

Neste texto, abordamos a representação da sociedade patriarcal repressora do início do século XX pela perspectiva da escrita de Andradina de Oliveira. 0 livro $O$ Perdão (1910) é revelador do discurso dominante nesse período e apresenta personagens mulheres movidas pelo sentimento de transgressão ao assumirem 0 seu desejo sexual. Sob a ótica dos estudos de gênero, buscamos evidenciar os questionamentos e rupturas das 
práticas de dominação apresentados pela escritora Andradina de Oliveira em um romance urbano ambientado na Belle Époque rio-grandense.

Entradas para indexação

KEYWORDS: Woman; Patriarchal society; historiography; Andradina de Oliveira.

PALAVRAS-CHAVE: Mulher; Sociedade patriarcal; historiografia; Andradina de Oliveira.

\section{Texto integral}

\section{INTRODUÇÃO}

Na sociedade patriarcal, o silêncio permeava as relações da mulher com o parceiro e com a sociedade. "Aceitar, conformar-se, obedecer, submeter-se e calarse” (PERROT, 2005, p.10) eram o panorama histórico da época em que Andradina de Oliveira escreveu as suas obras e atuou na liderança da Revista Escrínio. Os estudos da autoria de mulheres e a invisibilidade das obras produzidas por elas, e ignoradas pelo cânone em diversos contextos, tem colocado em questão as condições sociais que permitiram, de forma natural, a sua inferiorização. Obras de autoria de mulheres passaram despercebidas e foram, propositalmente, relegadas ao esquecimento, o que se configura como uma "negação a todas as escritoras do período, de acesso ao poder simbólico investido no estatuto da autoria. A autoria significa a inscrição de um sujeito no espaço sócio-histórico dos discursos que circulam em uma dada sociedade" (SCHMIDT, 2012, p. 65).

A crítica feminista, dentro dessa perspectiva, tem se ocupado em revitalizar obras de autoria feminina, que, pelos motivos citados, ficaram invisíveis perante o cânone: "o século XIX, na literatura brasileira está repleto desses exemplos; foram descobertos até mesmo textos de dramaturgia, gênero pouco explorado por mulheres" (XAVIER, 1999, p.20). A autora ressalta, ainda, que é importante o cuidado em não se valorizar esteticamente textos carentes de qualidades literárias: ser de autoria feminina não deve ser critério único para que sejam considerados bons textos. De qualquer maneira, o empenho em promover um trabalho revisionista possibilitou romances como 0 Perdão (1910) de Andradina América de Oliveira Andrade, tivessem uma compilação em livro.

Andradina América de Andrade e Oliveira nasceu no dia 12 de junho de 1864, filha do médico Carlos Montezuma de Andrada, e de Joaquina da Silva Pacheco, uma mulher de família de origem açoriana radicada em Rio Pardo, RS. Com a morte de seu pai, a família mudou-se para junto dos parentes maternos, em Rio Pardo e "Aos 17 anos casou-se com um alferes, e do conúbio, resultou o nascimento de seus dois filhos" (ARENDT; BORTOLUZZI 2012, p. 33). Entretanto, a morte do esposo, quando as crianças ainda eram pequenas, trouxe uma série de percalços financeiros para a família". Foi nesse momento que Andradina rompeu com os padrões instituídos para adentrar no mercado de trabalho, ato inaceitável para a época. Assim, quando seus filhos Adalberon e Lola ainda eram pequenos, Andradina "lecionou, editou livros, fez palestras e conferências remuneradas, quando se esperava da mulher que 
permanecesse nos afazeres do lar, na costura e nos bordados" (FLORES, 2007, p. 11). A ousadia da escritora despertava, segundo ela própria, "a crueldade dos invejosos, a maledicência dos mulos, a pequenez dos egoístas que procuravam ferir a mulher que tinha arrojo de trabalhar pela inteligência e arrimo dos seus" (OLIVEIRA, 1908, p.84):

Andradina de Oliveira, confessa militante em prol dos direitos femininos, aproveitava para denunciar o aprisionamento a que vivia submetida a mulher na esfera privada. Solicitava, também, às leitoras que enviassem material jornalístico, a fim de ser publicado, para o endereço do escritório da redação, instalado na Rua General Caetano Gonçalves, próximo à Beneficência Portuguesa, em Bagé (RS) (ARAUJO, 2008, p. 113).

Andradina lecionou em Pelotas - RS, e em Rio Grande, onde estreou como escritora. Depois, lecionou em Bagé - RS. No ano de 1989, fundou o periódico Escrínio - Jornal literário artístico e noticioso. Santos acrescenta que Andradina acreditava na importância do jornal como meio de divulgação da capacidade intelectiva da mulher da época, o que fica evidenciado no editorial do primeiro número do periódico: "surge também como um incitamento à mulher rio-grandense, convidando-a a romper o denso casulo de obscuridade e vir à tona do jornal trazer as pérolas de sua cultivada inteligência" (SANTOS, 2010, p. 50). É latente a postura emancipatória da escritora, ao chamar as mulheres para uma causa comum a todas da época.

E foi escrevendo que Andradina de Oliveira fez de seu trabalho intelectual sua principal fonte de subsistência, desafiando a norma patriarcal vigente. Em 1907, já havia publicado A mulher rio-grandense: escritoras mortas, fruto de muitas pesquisas e viagens ao interior do Estado, realizadas em companhia de sua filha Lola. Ambas produziram peças e viajaram com o intuito de divulgar seus trabalhos, tanto no Brasil como no exterior. Suas conferências ajudavam na exposição de seus ideais. Flores (2011) destaca que Andradina, com a filha, fez uma turnê entre 1915-20, por Montevidéu, Buenos Aires, Paraguai e Mato Grosso. Em 1920, mudaram-se para Jaú, depois Ribeirão Preto e São Paulo. Pela menção feita a ela na revista A Violeta, onde publicava textos assiduamente, há a suspeita de que as duas moraram por um tempo em Cuiába-MT, de 1917 a 1919. A menção também nos possibilita afirmar que Oliveira conseguiu receber, em vida, um certo reconhecimento:

Cuiabá terá a ventura de hospedar a ilustre escritora e conferencista Me. Andradina de Oliveira (e a filha) que há algum tempo vêm fazendo uma tournée literária por diversos estados do Brasil. Depois de uma estadia em Corumbá onde a imprensa teceulhes lisonjeiros elogios, esteve em São Luís de Cáceres e agora teve a súbita gentileza de nos comunicar que visitará Cuiabá proximamente tenho seguido pelo Nioac. A Violeta apresenta-a ao nosso público, certa de que a ilustre escritora muito o satisfará $(A$ VIOLETA, apud FLORES, 2009, p. 716). 
Andradina de Oliveira, portanto, se configura como uma vez que rompeu com os discursos impostos e que, embora invisibilizada pela historiografia literária, deixou um legado que merece ser recuperado. Norma Telles (2002) considera que o século XIX foi marcado por profundas transformações, mas não se pode esquecer que esse século foi sombrio para as mulheres e para os colonizados. Nesse período, surgiram alguns movimentos sociais, o socialismo, os feminismos e a Nova mulher. Foi também o século do romance, que coincidiu com a ascensão da sociedade burguesa. 0 romance moderno deixa de lado as formas de ficção anteriores, as mitologias, as lendas ou fontes literárias do passado, e passa a apresentar a prosa da vida doméstica. Já o romance burguês privilegia a diversidade do espaço urbano como um registro indentitário, a partir de personagens representadas de forma realista. A subjetividade característica do Romantismo dá lugar à objetividade das ideias do Realismo, propondo uma investigação do comportamento humano, a crise das instituições, os conflitos interiores, como ponderou Andradina de Oliveira:

Após 1850, o modelo idealista do amor romântico desagrega-se. 0 campo semântico do sentimento compõe-se ainda dos mesmos elementos, mas já começando a se desintegrar. A ironia flaubertiana atesta o fim das crenças angélicas no amor, a perda de fé nos emblemas românticos, paralela à sua difusão e à sua tendência a tornar-se um objeto de consumo (ANDRADE, 2013, p. 66).

O Perdão acompanha a efervescência da sociedade burguesa, apresentando também o desnudamento do casamento. Nesse romance, temos a personagem Estela, que, assim como outras narrativas clássicas do realismo, se apaixona pelo primo que vem de fora. Para Watt (2007), o termo realismo esconde uma característica marcante do gênero romance, e afirma: "Se este fosse realista só por ver a vida pelo lado mais feio não passaria de uma espécie de romantismo às avessas" (WATT, 2007, p.06). Essa afirmação se refere ao realismo como apenas um modelo literário que "rebate" os ideais românticos característicos do século XVIII, mas, na verdade, procura retratar a experiência humana, seu realismo não está na espécie de vida apresentada, e sim na maneira como a apresenta.

Nesse meio, a mulher "passou a ser alvo de uma verdadeira tecnologia do poder em termos de normalização de uma identidade e de um corpo compatível com um projeto progressista, mas de fundo conservador e patriarcal" (OLIVEIRA, 2010, p.13). E a literatura de autoria masculina também contribuiu com essa tecnologia, e se encarregou de representar as personagens femininas de acordo com as construções sociais edificadas, "não necessariamente por seus autores, mas pela cultura a que eles pertencem, para servir ao propósito da dominação social e cultural masculina" (ZOLIN, 2009, p.226).

Schmidt (2008) lembra que na construção da literatura nacional, ou de sua identidade, não participaram mulheres. Elas não foram reconhecidas como sujeitos do discurso e da cultura, o lugar dado à mulher foi a margem, visto que "essa lógica 
sustenta as oposições binárias, sistema estruturante de privilégio e exclusão que ratifica a posição central e normativa do sujeito masculino, segundo o modelo identitário de referência da cultura branca patriarcal ocidental" (SCHMIDT, 1999, p.26):

Basta olhar para história do nosso passado para perceber o subtexto de dominação e os mecanismos de exclusão que geriram o nosso processo cultural [...] conjugado pela visão etnocêntrica e patriarcal cuja estratégia sempre foi a redução da diferença à força do mesmo, a nossa cultura projetou a ilusão de homogeneidade graças à ação de um violento processo de repressão, uma recusa em aceitar as marcas significantes do outro (SCHMIDT, 1999, p.186).

Para Xavier (1999), é significativo o fato de que as escritoras, até meados do século XX, "com exceção de Lúcia Miguel Pereira, não tenham se ocupado com a crítica literária, dominada pelo gênero masculino". As escritoras existentes foram julgadas pelos críticos homens que lhe conferiam um valor segundo os padrões dominantes da época. Sendo assim, muitas contistas, poetisas, romancistas e dramaturgas optaram por usar "pseudônimos, ou até mesmo, pelo absoluto anonimato, para escapar da rejeição pública, quando não, do próprio escândalo" (XAVIER, 1999, p.18). Sobre o tema, argumenta Terezinha Schmidt:

É nesse sentido que a recuperação e a busca de inserção da autoria feminina na narrativa histórica de construção da literatura brasileira do século XIX têm levantado uma série de questões de fundo sobre a constituição do nosso passado literário e sobre como esse passado, seus valores e regimes de representação, são reproduzidos no rastro de heranças do poder patriarcal que se desdobra em poder cultural, institucional, teórico e interpretativo. (SCHMIDT, 2012, p. 65).

No século XIX, reinava o discurso crítico conservador. Uma escritora que questionasse as regras impostas, não seria bem aceita, como foi o caso de Andradina de Oliveira. Ela fez de seu jornal Escrínio um importante veículo de suas obras, e de divulgação de suas ideias. 0 que se pensava a respeito dessas mulheres era que: "mulheres que se desviavam de suas funções ditas 'naturais' colocavam em risco sua feminilidade e sua reputação; escrever significava entrar num território proibido por uma tradição milenar" (SCHMIDT, 1999, p.56). 0 Perdão trazia uma discussão a respeito do direito da mulher sobre seu corpo, ao assumir a sua sexualidade, e frisa também, na voz das personagens, que o divórcio deveria ser legalizado. Já no periódico Escrínio, Andradina de Oliveira foi uma militante dos direitos das mulheres, denunciando o aprisionamento a que estavam submetidas no âmbito privado.

A representação e o protagonismo de escritoras causam um deslocamento, abrindo espaços de resistência ao poder imperante. A "abertura ao outro, àquele que 
não pensa como nós, que é ele mesmo, em sua diferença e sua originalidade" (CARVALHAL, 2003, p.29) são importantes para entender a luta contra as instituições patriarcais. E são muitas as escritoras que estão emergindo do passado para integrar a historiografia literária brasileira, uma delas é Andradina de Oliveira.

\section{REESCREVENDO A HISTORIOGRAFIA LITERÁRIA COM ANDRADINA DE OLIVEIRA}

Os discursos intrinsecamente atrelados ao imaginário social são revisitados No romance $\mathbf{O}$ perdão. A narrativa retrata uma típica família burguesa, composta por pai, mãe, filhos, agregados, familiares e criados. Apresenta um núcleo central representado pelo chefe da família, pela esposa e pelos filhos legítimos; e contava ainda com membros subsidiários (parentes, filhos ilegítimos ou de criação, afilhados, amigos, serviçais, agregados e escravos). Além da família, há o primo Armando, que se torna um agregado da casa, a tia Zina, que desempenha um papel assistencialista, alimentando semanalmente as pessoas pobres da região. Nesse mesmo núcleo de personagens, a cozinheira Eva dá ordens aos demais criados, e ajuda Tia Zina na sua boa ação:

Sempre aos sábados era, para Eva, certa aquela maçada. Ficava então deveras estonteada com o panelão de cozido, donde haviam de sair, que chegassem, a carne, os legumes, o pirão e a sopa. Resmungando pôs-se a cortar a vianda em tantos pedaços quantos os pobres - cambuíada de vadio! E a gente que se amole, que se alevante co'escuro, prá enchê a pança dos vagabundos!

- Eva! Chamou, de mansinho, a tia Zina, entrando na cozinha, com um grande ramalhete de rosas. Botaste bastante couve, abóbora, batata e aipim no cozido dos pobres? (OLIVEIRA, 2010, p. 60).

As personagens, por meio de seus conflitos, ocasionados pelas divergências de seus pontos de vista, questionam os valores morais existentes. Elas expressam seus desejos mais íntimos e também tecem comentários críticos sobre temas polêmicos como casamento, maternidade, adultério, dentre outros. Nesse universo ficcional, as mulheres têm voz e expressam suas opiniões sobre o contexto em que vivem, permitindo, assim, que a narrativa apresente uma pluralidade de vozes. 0 enredo é conduzido por um narrador onisciente, que proporciona uma visão mais ampla dos fatos. No enredo, as representações de gênero e os diálogos femininos e masculinos expõem as diferenças no modo de pensar, focalizados principalmente nas reflexões das personagens do romance.

No final do século XIX, "a geografia da cidade se transforma. Reorganiza-se o espaço urbano, tendo em vista uma nova orientação política e econômica" (CORREA, 1993, p. 21). A paisagem urbana se modifica, e Porto Alegre é o maior porto comercial do estado do Rio Grande do Sul, porta de entrada para as principais transações comerciais e culturais. São novos bairros, praças, ruas pavimentadas, 
casas comerciais, bancos, cabarets, cinemas e tantos outros estabelecimentos que modificaram a paisagem urbana da cidade. Nesse meio, o espírito da Belle Époque (1871 a 1914) foi incorporado pela burguesia da região. Em O Perdão, percebemos como os sujeitos vivenciaram essa modernidade em seu cotidiano, no início do século XX. Na cena inicial, a família está em grande ascensão e os negócios só prosperam. As descrições presentes no romance dão conta da mistura e das combinações da urbanidade em construção. A história trata de uma família tipicamente burguesa, tendo como patriarca Leonardo de Souza, um rico produtor do setor agropastoril, casado com Paula, que são os pais de Estela, Celeste e Lúcia. No início da trama, tudo parece aparentemente tranquilo, o relacionamento de Paula com Leonardo, a prosperidade crescente, as inúmeras qualidades de suas filhas. Todos representam seus papéis sociais preestabelecidos, cumprindo os ideais daquela sociedade. A cena de um jantar familiar nos remete a uma imagem de grande ostentação:

Daí a uma hora toda família sentava-se à mesa. 0 fazendeiro, num terno de brim branco, muito elegante, camisa de seda lilás, penteado cuidadosamente, perfumado à Pinaud, com um sorriso de plena satisfação física e moral, estava à cabeceira da mesa, evidenciando um apetite sadio. Paula, à direita, vestia de ponge róseo peignoir plissado, coberto de rendas valencianas e fitas liberty, donde emergiam os braços roliços com argolões de ouro, as mãos pequeninas cheias de anéis e a garganta alta e escultural (OLIVEIRA, 2010, p. 39).

A família reunida permite visualizar como se estruturava essa sociedade. Todos à mesa, a figura paterna imponente, ocupando seu lugar de provedor e controlador das mulheres da casa, exemplifica muito bem a imagem de uma classe social em ascensão. Outra imagem retratada é a satisfação "moral" de manter o status de família perfeita, com sua esposa dedicada ao lar e suas filhas castas e aptas para a função social do casamento. Importante lembrar que a família nuclear e conjugal, tratada e regulada, tornou-se um referente histórico da família burguesa:

Criou a figura do indivíduo contido, polido, bem educado, cuja norma ideal é o comportamento reprimido e disciplinado. Mas as culpas de uma crescente tendência a autoculpabilização, que se tornou marca registrada do sujeito civilizado e aburguesado. Do sujeito forçado a exercer um autocontrole tirânico sobre si mesmo (COSTA, 1983, p. 14).

Uma nova identidade urbana era formada e essa paisagem foi representada nas obras de Oliveira. Para D’incao, “nas casas, domínios privados e públicos estavam presentes. Nos públicos, como nas salas de jantar e os salões, lugar das máscaras sociais" (2012, p. 228). Essas máscaras sociais serviam para esconder a repressão vivida, que era difundida pelo discurso médico e higienista existente na 
época. Esse novo sujeito que se apresenta para sociedade, em sua casa, tem outro comportamento.

\begin{abstract}
A educação sexual, que, segundo a higiene, deveria transformar homens e mulheres e reprodutores e guardiões de proles sãs e raças puras conseguiu, em grande parte, estes objetivos. A sanidade física da família de elite aumentou, na medida em que as condutas sexuais masculinas e femininas foram sendo respectivamente reduzidas às funções sócio sentimentais do pai e da mãe. Em contrapartida, esta mesma educação desencadeou uma epidemia de repressão sexual intrafamiliar que, até bem pouco tempo, transformou a casa burguesa numa verdadeira filial da polícia médica (COSTA, 1983, p. 15).
\end{abstract}

A família descrita no início do primeiro capítulo nos remete a uma imagem de perfeição, todos muito felizes, inclusive os empregados que servem a família do fazendeiro com devotamento, porém, ao longo da trama, esta representação será desconstruída. Temos a descrição das posses da família e de suas imensas lavouras de cana. Os dotes artísticos das filhas também são exaltados: tocam vários instrumentos, e diferentes sinfonias após o jantar. 0 salão de música ostenta o luxo, ali dedilhavam sinfonias de Bach, Mendelsohn, Wagner, Weber, e tantos outros clássicos importados da Europa. Para Maia, "os dados da diversidade cultural vai permear todo romance [...] a roupagem das pessoas, os móveis da casa, e a música que tocam vem da Europa" (2010, p.18).

A esse modo de vida, esteve incluído um novo jeito de pensar as relações e o comportamento das pessoas. As mudanças mais significativas foram relativas ao sujeito feminino. As amarras que a prendiam se afrouxaram um pouco, mas a mulher ainda estava ligada às suas funções de mãe e esposa. As novas formas de convívio social implicavam "novos modos de proceder tanto em relação ao outro (preocupação com o olhar público) quanto em relação à própria pessoa" (CORREA, 1993, p. 280). D'incao (2012, p. 228) considera que "em especial a mulher, submetiase à avaliação e opinião dos 'outros'. A mulher de elite passou a marcar presença em cafés, bailes, teatros e certos acontecimentos da vida social”. Se agora era mais livre, não só o marido ou o pai vigiava seus passos, havia o olhar da sociedade. No romance, Estela, a filha casada de Leonardo, vai a um baile acompanhada de seu primo Armando, e a reação das pessoas reflete esse olhar vigilante da sociedade:

-Ah! Mas tu estavas deslumbrante ontem! Como o encarnado te fica bem! Desde que entraste no camarote que me distraí da representação. Não me fartava de te admirar.

-Ora Comba...estás caçoando.

-E como dezenas de pessoas te binoculavam. Então os homens... Devoravam-te com os olhos! (OLIVEIRA, 2012, p. 152). 
Comportar-se em público era necessário porque a convivência de maneira educada mantinha as "máscaras sociais" (D'INCAO, 2012, p. 228). A representação diante das pessoas na convivência social era um "signo de civilidade" (CORREA, 1993, p. 29). Salas e salões das casas eram abertos para os saraus e leituras, além das músicas tocadas ao piano. Em 0 Perdão, essa prática é retratada na casa da família de Leonardo de Souza. O salão de música suntuoso "dava, ao entrar-se, a impressão de uma aula de instituto. Ao longo das paredes, forradas de papel vermelho- escuro, corriam armários envidraçados pejados de álbuns com os melhores autores" (OLIVEIRA, 2010, p. 44). Vejamos um comentário de Armando, recém-chegado do Rio de Janeiro, sobre Porto Alegre:

Os usos e costumes são os de centros adiantados. A cultura da mulher é já bastante apurada. As artes são aqui acolhidas com imenso carinho. Há gosto pela música e pela pintura. Cantam, bordam e vestem-se bem as mulheres. E são bonitas. As de sangue brasileiro e luso tem um salero diabólico...e as teutas...oh! as teutas [...] (OLIVEIRA, 2010, p. 105).

Os locais da elite eram definidos, assim como, do proletariado e dos imigrantes "italianos, dos judeus, do comércio, da indústria, das residências, do domínio público e do privado" (CORREA, 1993, p. 28). No romance de Andradina de Oliveira, percebemos a organização dessa hierarquia. Alguns criados são negros libertos, e a babá dos filhos de Estela é italiana. Todos com sua linguagem própria, carregada de suas particularidades: "cambuída de vadio! E a gente que se amole, que se alevante co'escuro, pra enchê a pança dos vagabundos!" (OLIVEIRA, 2010, p. 60).

Paula, mãe de Estela, adquire uma nova posição ao se casar com Leonardo. Para Maia (2010, p. 24), "a mobilidade social, transformadora de identidades, também é contemplada na referência à modificação do status social de Paula". 0 trecho refere-se ao casamento de Paula que lhe tirou da pobreza no mesmo momento que sua prima rica Birutinha perde toda sua fortuna com a morte precoce do noivo. Nesse caso, o casamento apresentou-se como uma das poucas possibilidades para uma mulher ter ascensão social e estabilidade financeira. Numa passagem do romance, é revelado o motivo que impulsionou a escolha de Paula por Leonardo:

O seu talento havia impressionado tanto quanto a sua majestosa beleza. Foi em um sarau, na residência de um amigo, que Leonardo a viu e ouviu pela vez primeira. E, loucamente apaixonado, depôslhe aos pés fortuna e nome. Paula era de uma família honestíssima, porém pobre [...] ela o compensou em carinhos, vindo a amá-lo imensamente (OLIVEIRA, 2010, p. 49).

Paula, assim, abdicou de seu antigo relacionamento com um moço pobre para alcançar destaque sendo uma mulher rica a desfilar pelos salões da alta sociedade. 
Essa personagem representa o ideal modelar do século XIX: "as mulheres ganhavam uma nova função: contribuir para o projeto familiar de mobilidade social através de sua postura nos salões como anfitriãs e na vida cotidiana, em geral, como esposas modelares e boas mães" (D’INCAO, 2012, p. 229). Havia uma valorização no papel materno das mulheres, na supervisão dos filhos: o cuidado inicial da primeira infância era das mães.

A mãe de Estela, Paula, consegue casar a filha com um rico comerciante da cidade. Após esse casamento, Estela torna-se mãe e junto a esse acontecimento chega Armando, sobrinho de Jorge, seu marido. Galanteador e boêmio, o jovem desperta emoções em Estela que, entre longas reflexões e "delírios", expõe na narrativa seus sentimentos e culpas. A trama passa a girar em torno de seu dilema moral. Rita Terezinha Schmidt, em sua apresentação do romance, na sua reedição de 2010, discorre que, no início do século XX, as mulheres eram "domesticadas segundo a razão normativa e civilizada da família produtiva, excluídas de exercerem sua cidadania pública por serem consideradas zeladoras da afetividade, do desejo e do corpo" (SCHMIDT, 2010, p. 22).

É nessa perspectiva que analisamos como as personagens femininas criadas por Oliveira estão posicionadas nessa sociedade. Em um primeiro momento, destacamos o confinamento no qual vivem as mulheres, seu legado é tocar piano, dar ordens aos criados, casar-se e procriar. Paula, a mãe da protagonista Estela, julga-se feliz com sua união, e tenta repassar todas essas condutas para sua filha. Em conversas sobre o casamento de Estela, Paula a indaga se realmente ama o noivo a ponto desejar se casar e Estela diz:

Jorge é um excelente partido! E talvez um dos rapazes mais ricos de Porto Alegre, elegantíssimo, bonito, veste-se muito bem, fala corretamente o francês e o alemão e está muito bem colocado. Já viajou pela Europa e tem culta educação [...]. Tenho já vinte anos, quero ter um lar, porque só dentro dele somos verdadeiramente rainhas (OLIVEIRA, 2010, p. 67).

Por essa citação, percebemos que não havia opção, a estabilidade para Estela era seu ideal de vida. Esta era "a única carreira para as mulheres; os homens têm 36 possibilidades, a mulher uma só; o zero como na roleta" (BEAUVOIR, 1980, p. 86). Devido a isso, Estela coloca Jorge como superior a todos os outros que a cortejaram, e evidencia que ele a ama em detrimento aos demais pretendentes. É claro que Jorge também buscou uma companheira que atingisse seus objetivos, uma vez que o matrimônio também beneficiava aos homens. Jorge era um dos rapazes mais ricos da cidade, elegante e educado, não poderia deixar de ser o marido ideal para Estela. Por outro lado, para ele, a pretendida também uma boa escolha, uma vez que era muitíssimo rica. A afirmação da personagem Estela, "somente no lar somos rainhas" (OLIVEIRA, 2010, p. 67), expressa o pensamento reinante na sociedade patriarcal em que se percebe o modo de vida da mulher, pautado em uma construção simbólica que, segundo Bourdieu (2012), "não se reduz a uma operação estritamente performativa de nominação que oriente as representações, a começar pelas representações de corpo" (BOURDIEU, 2012, p. 33). 
Ao conversar sobre seu destino, Paula, mãe de Estela, a adverte sobre a importância de se casar: "Minha filha, o casamento é o ato mais sério da vida da mulher...Não basta para a felicidade da mulher a fortuna, o nome, a posição e o saber de um homem. É preciso mais. É preciso o amor para ligar os dois corações" (OLIVEIRA, 2010, p. 65). Ao se casar, portanto, Estela adquire o status de esposa e, logo em seguida, de mãe de dois filhos. Estela se vê diante de uma casa aconchegante e sofisticada, onde ela reina absoluta. Como destaca em conversa com sua mãe, a decoração é extremamente requintada, adequada ao seu padrão de vida e Jorge é um exemplo de homem, elegante, terno e culto: "móveis modernos, vistosos, ricos, baixelas de prata e porcelanas raras, erguem-se elegantes" (OLIVEIRA, 2010, p.67). O casamento é uma instituição firmada na sociedade e, como toda instituição, possui regras estabelecidas, tornando-se uma instituição em que transcende para o interesse coletivo a "união econômica e sexual do homem e da mulher". Para Beauvoir (1980, p. 175), esse é um fato característico no regime patriarcal vivido por Estela, e que não assegurava uma felicidade individual.

Em um determinado trecho da obra, Estela pergunta à sua mãe: "o que é amor?". Jurandir Freire Costa defende que "o amor foi inventado como fogo, a roda, o casamento [...] é uma crença emocional, e, como toda crença pode ser mantida, alterada, trocada, melhorada ou dispensada" (1999, p. 12). Neste sentido, a pergunta de Estela reflete sua insegurança em relação ao matrimônio. Ela não conhecia o amor verdadeiro, apenas observou em seu pretendente todas as caraterísticas cabíveis ao seu modo de convivência, todos os requisitos que a família e a sociedade esperam. Nesse ponto, o amor é visto como algo a ser adquirido com a convivência: “[...]. Na falta de amor, ela terá pelo marido um sentimento terno e respeitoso chamado amor conjugal; ela encerrará o mundo entre as paredes do lar que será encarregada de administrar; perpetuará a espécie humana através do futuro" (BEAUVOIR, 1980, p. 194).

A ordem da sociedade era mantida com padrões que regimentavam até o amor, a família deveria ser estruturada, demonstrando grande simetria, cumprindo os ideais burgueses. Paula, ao ser questionada pela filha sobre seu casamento com Leonardo, diz que o amor apareceu com o passar dos anos, com a família constituída. 0 amor, caracterizado como crença emocional, a fez gostar de outro não por amor, mas sim, pelos seus bens e pelo seu devotamento a ela. É o que percebemos no diálogo entre as personagens:

Tu casaste por amor com o papai? Sei que só mais tarde vieste amálo.

Foi. Para que mentir. Meu caso era outro. Eu era paupérrima! Gostava é certo de um moço tão pobre como eu.

Estela, assim como sem amor não pode haver felicidade no casamento, também sem o conforto não há enlace possível. Pressenti mesmo que viria a amá-lo até mais que outro (OLIVEIRA, 2010, p. 35).

A problemática concernente ao casamento arranjado e a representação social da mulher perante uma moral instituída conduziram a personagem Estela, mais 
tarde, a interpretar os galanteios de Armando como um amor avassalador que não conhecera com Jorge. Ao final, Estela carregava sobre si o peso de conduzir um matrimônio que honrasse sua família, mas esta tarefa tornou-se difícil para a jovem mãe. A presença do primo Armando desestrutura o sólido casamento de Estela, tirar-lhe o sossego e, nesse contexto, seus sentimentos começaram a mudar, despertando-lhe um desejo sexual que não nutria pelo marido:

Eram lindíssimos seus dentes, os lábios rubros, o bigode novo, preto e fino. Uma onda de sangue subiu-lhe às faces. Era Armando que entrara. 0 rapaz acompanhou-a com olhos de fogo, contendose no doido anseio de segui-la. Desceu-os pelo corpanzil até a cinta larga, 'um bloco de carne malfeita como o diabo!' (OLIVEIRA, 2010, p. 94).

Estela, mergulhada em seus mais íntimos pensamentos, reflete sobre a vinda desse sobrinho vigoroso e jovem. Ela sabia de seu passado: vivia desregradamente e gastava todo dinheiro de sua família com mulheres. Jorge o trouxera para o sul para tirá-lo dos vícios. E seguindo a tradição das alianças familiares, Jorge fazia planos de casá-lo com a irmã de Estela, Celeste, "Apesar de muitas criancices de Armando, ela adora-o e tem nele grandes esperanças" (OLIVEIRA, 2010, p. 103). Armando, por sua vez, já estava focado na esposa de seu benfeitor. Já em Estela, a luta interior era contínua

\begin{abstract}
Amava imensamente o marido e estava segura de sua força, orgulhava-se do que valia e não iria jamais descer de seu pedestal. Demais, o seu Jorge era jovem e belo. Ninguém mais elegante que ele. $\mathrm{Na}$ intimidade, era sempre tímido, delicadíssimo como um noivo. E, outra vez, vinha-lhe à imaginação Armando, a gritar com força e volúpia, por todos os poros, a carne a fremir, os olhos a luzir como dois pecados (OLIVEIRA, 2010, p. 101).
\end{abstract}

A presença de Armando a faz pensar no perigo iminente de se ter um jovem a sós com ela em casa. Jorge, rico comerciante, passa muito tempo fora de casa, e Estela vê isso como um mau presságio sobre o que poderá acontecer. Para Maia (2010, p. 78), "não se pode esquecer que o corpo feminino estava, então, preso à repetição do cotidiano e à inevitável paralisia recorrente desta situação, ao passo que o corpo masculino circulava livremente nos espaços públicos". A protagonista passava todo seu tempo em casa. Mesmo que a sociedade de seu período estivesse vivendo grandes mudanças, é possível perceber, na obra, a resistência em aceitar a mulher ocupando novas posições fora do lar. Esse cotidiano vivido por Estela é abalado definitivamente com a presença do primo Armando, resultando em seu grande dilema existencial.

Armando já não "a tratava com o antigo respeito, a estima dos primeiros tempos, quando viera morar com o tio [...] dera pra chegar antes dele agora e a 
dirigir-lhe galanteios, a olhá-la com olhos desonestos" (OLIVEIRA, 2010, p. 99). Estela não é capaz de mentir ou enganar o seu parceiro como sua amiga Comba, e fica numa "encruzilhada moral". Prevendo o julgamento da sociedade, a própria personagem passa a se condenar. Armando, jovem, boêmio, e estudante, ocupa os lugares públicos e não está preocupado com o escândalo, mas sim em seu interesse em Estela. Segundo Bourdieu:

Enquanto os homens tomam maior lugar com seu corpo, sobretudo em lugares públicos. Essa espécie de confinamento simbólico é praticamente assegurado por suas roupas (mais evidente em épocas distintas) e tem por efeito não só dissimular o corpo, chamálo à ordem, sem precisar de nada para prescrever ou proibir explicitamente (BOURDIEU, 2012, p. 38).

De início, Jorge confia em Armando para fazer companhia à Estela, quando ele estivesse ausente. Isso passa a ser um problema para ela que, já na primeira noite, recolheu-se aos seus aposentos, temendo o pior. A pressão de Armando aumenta quando o mesmo percebe a falta de resistência da tia. Isto o encoraja a prosseguir. A educação de Estela não admitia falhas desse tipo; se cedesse, seria consumida pela culpa de ser a destruidora de seu lar. Fora educada para não falhar e não decepcionar a família e a sociedade. Segundo Beauvoir:

\begin{abstract}
A própria mulher estima que, em casando, assumiu encargos, quer ser 'uma mulher de verdade', quer ser elegante, boa dona de casa, mãe dedicada como o são tradicionalmente as esposas [...] faz questão de, já o vimos, de não falhar em seu destino de mulher [...] Educada no respeito à superioridade masculina, é possível que estime ainda que cabe ao homem ocupar o primeiro lugar; por vezes teme também, em o reivindicando, arruinar o lar; hesitando entre o desejo de se afirmar e o de se apagar, fica dividida, estraçalhada (BEAUVOIR, 1980, p. 464).
\end{abstract}

Em meio aos seus pensamentos controversos, Estela pensa no quão perigoso para sua imagem poderia ser um relacionamento extraconjugal, afinal, "a família não é apenas um patrimônio. É também um capital simbólico de honra. Tudo o que arranha sua reputação, que mancha seu nome, é uma ameaça" (PERROT, 1991, p. 266). Além disso, para Estela, trocar a vida de luxo que tinha para viver um novo amor não estava em seus planos. Nesse âmbito de confusão de sentimentos, Armando e Estela ficam a sós:

A moça tinha a cabeça tombada no respaldo. Ele olhou-a assim. Era formosíssima. 0 luar agora batia-lhe em cheio no rosto e no colo que arfava. Armando não pôde conter-se. Apertou com as mãos 
geladas a cabeça da moça e imprimiu-lhe na linda boca um beijo de fogo, prolongado e doido (OLIVEIRA, 2010, p. 110).

Estela sente-se culpada e fecha-se em sua alcova assustada: "Fora muito culpada. Parecia-lhe até que já estava poluída” (OLIVEIRA, 2010, p.100). Envergonhada, pensa na mãe, nas irmãs, na sociedade, em seus filhos, e muito mais em Jorge. Queria negar que estava apaixonada, mas ao lembrar-se "daquele beijo de morte, nunca sentira emoção igual! Nunca!” (OLIVEIRA, 2010, p. 100), sentia-se impura perante os olhos da sociedade. Estela "encaminhou-se trôpega, cega de emoção. 0 rapaz seguiu-a suplicante. Então uma onda de sangue subiu-lhe às faces e ela soltou um grito de revolta: - Senhor!" (OLIVEIRA, 2010, p. 100). Para Bourdieu, a mulher sofre dessa forma, porque:

\begin{abstract}
Elas existem primeiro pelo, e para, o olhar dos outros, ou seja, enquanto objetos receptivos, atraentes, disponíveis. Delas se espera que sejam "femininas", isto é, sorridentes, simpáticas, atenciosas, submissas, discretas, contidas ou até mesmo apagadas [...] incessantemente sob o olhar dos outros, elas se veem obrigadas a experimentar constantemente a distância entre o corpo real a que estão presas, e o corpo ideal, do qual procuram infatigavelmente se aproximar (BOURDIEU, 2012, p. 82).
\end{abstract}

Em face da opinião alheia, sua atitude seria condenável, pois sabia de sua obrigação em cumprir e/ou representar um papel na sociedade. Seu desvio de conduta ocasionou a culpabilização exagerada perante aos seus novos desejos despertos. Segundo Costa (1983, p. 17), "a normalização das condutas e sentimentos opera em outro nível. Ela procede de forma oposta, despotilizando o cotidiano e o inscrevendo nas micropreocupações em torno do corpo, do sexo e do intimismo psicológico". Em suas lamentações, sentia-se que: "Era culpada. E bem culpada. Porque não se recolhera cedo? Depois...vestia-se de maneira imprópria para uma mulher casada, mãe de dois filhos, uma senhora. Estava com um trajo mais de cortesã em intimidades, com os braços nus, o colo provocando (OLIVEIRA, 2010, p. 117).

A realidade que a personagem vive se assemelha a de muitas mulheres que viveram nesse período, pois, para uma mulher que fora educada para o casamento, qualquer deslize poderia mudar completamente sua posição de honradez. Nas palavras de Maia, "a norma patriarcal é tão forte que, antes de qualquer condenação externa, ela própria se condena com o máximo rigor, incapaz de enfrentar o opróbrio da sociedade" (2010, p. 79). Flertar com alguém, dessa forma, era inaceitável, pois seria vista como impura. As imposições que sobrecarregam a personagem são tantas que Estela chega a desconfiar que suas vestimentas são sensuais e provocativas, de alguma maneira. Beauvoir assevera que: 
[...] a toalete não é só um adorno. Exprime, já o dissemos, a situação social da mulher. Somente a prostituta, cuja função é de objeto erótico, deve manifestar-se sob este aspecto único (roupas sensuais, cetins, maquiagem excessiva, saltos, denunciam a profissão). A qualquer outra mulher lhe censura "vestir-se como uma puta" suas virtudes erráticas acham-se integradas na vida social e não devem apresentar-se senão sob este aspecto bem comportado (BEAUVOIR, 1980, p. 298).

Convergindo com a citação de Simone de Beauvoir, Pierre Bourdieu esclarece que "tendo necessidade do olhar do outro para se constituírem [as mulheres], estão orientadas em sua prática pela avaliação antecipada de sua maneira de portar o corpo ou exibi-lo" (BOURDIEU, 2012, p. 83). Entende-se que essa constatação do campo social-cultural atinge Estela, pois fora previamente advertida, criada com todas as recomendações possíveis sobre o comportamento da mulher. Assim, a sua atitude ingênua poderia custar-lhe a moral perante a sociedade.

Armando também faz uma reflexão sobre a relutância de Estela em se entregar a ele. Aquele beijo fora o passo inicial para fazê-la sucumbir; além disso, julgava o desempenho de seu tio, achava que ele, Armando, seria o homem ideal para ela e que seria somente uma questão de tempo. Para ele, era inevitável que a atração mútua dos dois não resultasse no adultério, portanto, em sua fala, estava uma visão masculina, de quem não seria apontado posteriormente nos bares e cafés da cidade. Por outro lado, Estela carregaria essa marca, pois "a honra da mulher está guardada na carne e é frágil como vidro: uma vez estilhaçado, impossível colar" (MAIA, 2010, p. 79):

As mulheres só receiam o escândalo... o freio dos preconceitos não as impede de cair. Bem estúpida era a sociedade com a sua moral. Impossível dominar o ímpeto feroz da carne! 0 desejo é um chacal que se tem dentro para impelir para o pecado. E no pecado estava o que de melhor havia na natureza humana - o amor (OLIVEIRA, 2010, p. 118).

A visão do dominador é esta, a de uma Estela frágil, fraca e servil. Armando sabia que, se investisse, ela cederia, reforçando a ideia da mulher como "a parte mais fraca": "A mulher só se iguala ao homem fazendo da sua vida uma perpétua oferenda, como a do homem é uma perpétua ação" (BEAUVOIR, 1980, p. 437). Além de todas as imposições sofridas por Estela, Armando sabia que havia muitos fatores que a impediam de aventurar-se. Paralelo às investidas de Armando e lamentações de Estela, está sua irmã Celeste, que nutre um amor secreto por ele. Comba, amiga de Estela, que é liberal e mantém um relacionamento extraconjugal, confidencia a ela que não tem coragem de se libertar de seu casamento, e lhe expõe sua infelicidade: "O meu infortúnio provém, certamente, de me haver casado sem amor com Valério. Ele também não me estimava. Um desejo somente. Meu casamento foi feito mais pela 
vaidade da mamãe. Ela teve um sonho que realizou: casar com doutores as três filhas" (OLIVEIRA, 2010, p. 153).

O círculo de convivência de Estela agrega poucas amizades, mas Comba sempre a visitava e lhe confidenciava seus problemas, fazendo críticas à hipocrisia de seu relacionamento com Doutor Valério. Para Beauvoir, as amigas juntam-se "para criar um contra-universo cujos valores superem os valores masculinos; reunidas encontram força para sacudir suas cadeias [...] contestam com ironia a superioridade moral e intelectual do marido e dos homens em geral" (BEAUVOIR, 1980, p. 309). Comba contesta o casamento e a sua indissolubilidade: "Consequências da indissolubilidade do nó matrimonial. Viesse o divórcio e estava tudo remediado. Eu casava-me com o Ricardo e o Valério com a tipa" (OLIVEIRA, 2010, p. 157). Estela, por sua vez, passa-lhe a ideia de estar numa relação perfeita, sem deixar transparecer a sua inclinação por Armando. Esse impasse representa a grande armadilha do casamento imposto: "a mulher é mais escrava do homem pela gratificação de seus desejos que o homem é da mulher. 0 duplo padrão permite que os homens procurem gratificar-se fora do casamento, mas proíbe a mulher de fazer o mesmo" (LAQUEUR, 2001, p. 249).

Os jogos de poder estão presentes nas relações, tanto de Estela, de sua mãe Paula ou de Comba. Paula afirma que, se casando com um homem rico, poderia ser feliz, amou Leonardo depois de casada. Estela está às voltas com um sedutor galante, e repensa seu casamento, que também teve como critério de escolha um homem culto, rico, charmoso, que julgou ser superior aos que a cortejavam, e, por fim, Comba, que se sente livre para ter um amante. Esses tipos de relacionamentos representam a hipocrisia da alta sociedade da época, que, em busca de um padrão para seguir, acabam por resultar em frustrações e desencontros entre eles. No fim, não conhecem ou provam do amor que tanto é expresso nas vozes das personagens femininas na literatura romântica. E continuam, sem resposta para a pergunta incessante que as inquieta: "você se casou por amor?".

Após um ano desejando e, ao mesmo tempo, fugindo de Armando, Estela é convencida por ele a abandonar tudo e irem juntos para sua terra natal, o Rio de Janeiro. De forma eloquente, ele argumenta: "Dou-te minha vida, meu talento...a minha mocidade toda! Queres partir? Aqui não podemos ficar" (OLIVEIRA, 2010, p. 192), e assim tramaram a fuga para o dia seguinte. Estela, nervosa, diz aos criados que faria uma viagem para tratamentos médicos. Não foi fácil para a personagem conciliar sua vida conjugal com os seus desejos. A vida privada, moldada pela moral religiosa, produziu na personagem sua grande desventura. 0 conflito sentimental vivido por ela reflete como o modelo de vida familiar, promovido pela burguesia, foi paradoxal: "[...], a ética que ordena o convívio social burguês, modelou o convívio familiar, reproduzindo, no interior das casas, os conflitos e antagonismos de classe existentes na sociedade. As relações intrafamiliares se tornaram uma réplica das relações entre classes sociais" (COSTA, 1983, p.13). No vapor que seguia para o Rio de Janeiro, a personagem sente-se mal, fica sozinha e reflete: "Para todos os crimes do homem há atenuantes; para os erros da mulher só há agravantes. Não se lhe perdoa a ignorância, a paixão, o verdor dos anos, a inexperiência de vida" (OLIVEIRA, 2010, p. 240).

Em sua voz, fica evidente o peso de ser mulher. Enquanto ela estava aos prantos no leito do navio, Armando tocava piano e cantava para as pessoas a sua 
volta. Tomada angústia e arrependimento, a personagem sobe na amurada do navio e "um frêmito de heroicidade, pujante, sublime, agitou toda sua alma despedaçada [...] purificada e redimida da culpa! Aquela água não lavaria a mácula de seu corpo!? Ergueu os olhos, o céu era doce e tranquilo... lá encontraria seu perdão...." (OLIVEIRA, 2010, p. 304). E, assim, Estela se suicida.

Durante o percurso do enredo, Estela sentiu-se culpada e sempre questionou o que iriam pensar dela. Estela era constantemente visitada pelo passado, fora criada para casar, manter seu corpo ao serviço de uma "racionalidade funcional" (SCHMIDT, 2012, p. 19). Estela fora educada para ser boa esposa e mãe. Seu meio de convívio não aceitaria uma adúltera, um poder simbólico a rodeou, o poder latente que dita como as mulheres devem ser, sujeitando-as. Esse poder também a silenciou, de tal modo que levou Estela a cometer suicídio. 0 título do romance está distribuído nas entrelinhas de seu texto e estaria associado aquilo que a personagem buscava: o perdão de todos que a cercavam.

A voz narrativa elucida o momento de redenção da personagem Estela no momento em que ela olha para o céu como se apenas no plano espiritual fosse possível encontrar o perdão, “o padrão narrativo aponta a inevitabilidade do suicídio das personagens muito antes da morte 'real' a morte física é uma corroboração da morte psíquica anunciada através de uma série de indícios textuais" (SCHMIDT, 2012, p. 14). Esse final poderia ser um prenúncio do engajamento feminista das escritoras brasileiras no final do século XIX. O suicídio da personagem Estela carrega uma crítica social à vigilância dos corpos e anulação da sexualidade feminina plena. 0 que está implícito no ato de Estela é desvelado no decorrer da obra, questionamentos aos padrões impostos pela sociedade burguesa moralizante. A personagem se redime quando seu corpo é levado pelas águas, um gesto que, sem dúvida, deixa uma mensagem sobre o que gerou a domesticação dos corpos, a transgressão.

\section{CONSIDERAÇÕES FINAIS}

Ao analisar o romance 0 perdão, sob a ótica dos estudos de gênero, observamos as relações de poder explicitadas na voz das personagens. Em $\mathbf{0}$ Perdão, fica evidente o seu posicionamento em defesa do direito ao divórcio, além de trazer uma visão diferente da mulher. A versão existente era a da personagem idealizada pelos romances escritos por homens, e consagrados pelo cânone. Nas obras de Andradina, por meio da mobilidade da focalização, os juízos de valores e os posicionamentos críticos são expressos nas vozes das personagens e na representação dos papeis. A voz é dada às personagens femininas que expõem as dificuldades em conciliar sua vida conjugal e social, mantidas dentro da norma vigente. A força simbólica da sociedade julgadora impelia Estela cada vez mais para a reclusão, a ansiedade e a culpa pelos seus atos. Seus diálogos demonstram isso. 0 romance também é marcado pela denúncia e o desejo de ruptura dos padrões da sociedade patriarcal burguesa da época.

Muitos padrões de comportamento limitaram o mundo das mulheres. Elas foram sujeitadas a crer que somente o casamento indissolúvel seria sua função 
natural. A transgressão a esse sacramento era punida com o divórcio não legalizado e com as acusações da sociedade. Todas essas condições subtraem da mulher a sua expressão de desejo, uma estratégia que perdura por gerações com uma função de controle social. As convenções que segregaram a mulher ao reduto do lar, segundo Foucault, são fruto de uma sociedade burguesa perversa e hipócrita que, através dos discursos e instituições, tentou erguer uma barreira rigorosa contra a sexualidade, fazendo, assim, germinar a perversão, o poder que foi exercido sobre os corpos, reduzindo as sexualidades (FOUCAULT, 1979, p. 46). 0 que pode ser comprovado com o desfecho trágico, uma vez que a transgressão de Estela não seria perdoada pela sociedade.

Quando obras escritas por mulheres são revisitadas, o resultado é esse, uma abertura para repensar o cânone e, sem dúvida, recuperar livros julgados como inferiores porque todas as funções das mulheres eram direcionadas ao bem-estar da família, não havia abertura para se expressarem. Com a revisitação dessas obras, é possível descortinar a estrutura de uma sociedade sob o ponto de vista feminino. Pela escrita/voz de Andradina de oliveira e de suas personagens, refletimos sobre a hipocrisia de uma sociedade repressora, que desejava a todo custo normatizar a conduta das pessoas, gerando intensos conflitos morais.

\section{Referências}

BEAUVOIR, Simone de. 0 segundo sexo: a experiência vivida. 4 ed. Rio de Janeiro: Nova Fronteira, 1980.

BORTOLUZZI, Leticia Baron; ARENDT, João Cláudio. A obra Divórcio?, de Andradina de Oliveira, como prática emancipatória feminina. In: ZINANI, Cecil Jeanine Albert; SANTOS, Salete Rosa Pezzi. (Org.). Da tessitura ao texto: percursos de crítica feminista. 1ed.Caxias do Sul: Educs, 2012, v. 1, p. 9-351.

BOURDIEU, Pierre. A Dominação Masculina. Rio de Janeiro: Bertrand Brasil, 2012.

CORREA, Silvio Marcos de Souza. Sexualidade e poder na Belle Époque de Porto Alegre. Porto Alegre: Editora da Unisc, 1993.

COSTA, Jurandir Freire. Ordem Médica e norma familiar. Rio de Janeiro: Graal. 1983.

D'INCAO, Maria Angela. Mulher e família burguesa. In: DEL PRIORE, Mary; BASSANEZI, Carla (Orgs.). História das mulheres no Brasil. São Paulo: Contexto/UNESP, 2012. p. 223-240.

FLORES, Hilda Agnes Hübner. Dicionário de Mulheres. 2. ed. Florianópolis - SC: Editora Mulheres, 2011. 800p.

MAIA, Lúcia Henriques. 0 perdão, de Andradina de Oliveira: romance urbano na belle époque rio-grandense. Dissertação de mestrado, UFRGS-RS, 2010. 
OLIVEIRA, Andradina América de Andrade. 0 Perdão. Florianópolis: Mulheres, 2010.

OLIVEIRA, Andradina de Andrade e. FLORES, Hilda Agnes Hubner (Org.).

Divórcio? Porto Alegre: Ediplat / Florianópolis: Mulheres, 2007.

PERROT, Michele. (Org.) História da vida privada: da Revolução Francesa à Primeira Guerra. São Paulo: Companhia das Letras, 2005.

PERROT, Michele. (Org.) Minha história das mulheres. São Paulo: Contexto, 2013.

SANTOS, Salete Rosa Pezzi dos. Duas mulheres de letras: representações da condição feminina. Caxias do Sul, RS: Educs, 2010.

SCHMIDT, Rita. Cânone, valor e a história da literatura: pensando a autoria. feminina como sítio de resistência e intervenção. El Hilo de la Fábula, p. 59-74, 2012.

TELLES, Norma. Escritoras, escrita e escritura. In: DEL PRIORI, Mary (org.). História das mulheres no Brasil. São Paulo: Contexto/Edu-Unesp, 2002.

XAVIER, Elódia. Para além do cânone. In: RAMALHO, Christina (Org.). Literatura e feminismo: propostas teóricas e reflexões críticas. Rio de Janeiro: Editora Elo, 1999. p. 9-40.

ZOLIN, Lúcia Osana. Literatura de autoria feminina. In: ZOLIN, Lúcia Osana; BONNICI, Thomas. Teoria Literária. 3. ed. Maringá: Eduem, 2009.

\section{Para citar este artigo}

PINHEIRO, A. S.; SOUZA, S. A. 0 perdão, de Andradina de Oliveira: uma denúncia do discurso patriarcal. Macabéa - Revista Eletrônica do Netlli, Crato, v. 10, n. 7, 2021, p. 198-216.

As autoras

ALEXANDRA SANTOS PINHEIRO é graduada em Letras pela Universidade Estadual Paulista Júlio de Mesquita Filho, mestre em Letras-Literatura pela Unesp e doutora em Teoria e História literária pela Universidade Estadual de Campinas. Professora da Universidade Federal da Grande Dourados-UFGD.

SELMA ALVES SOUZA é mestre em Letras pela Universidade Federal da Grande Dourados-UFGD. Professora da Rede estadual de ensino de Dourados-MS. 